\title{
KLASIFIKASI PEMINJAMAN BUKU MENGGUNAKAN NEURAL NETWORK BACKPROPAGATION
}

\author{
${ }^{1}$ Norhikmah, ${ }^{2}$ Rumini \\ ${ }^{1}$ Program Studi Sistem Informasi, Fakultas Ilmu Komputer, Universitas AMIKOM Yogyakarta \\ ${ }^{2}$ Program Studi Informatika, Fakultas Ilmu Komputer, Universitas AMIKOM Yogyakarta \\ ${ }^{1,2} \mathrm{~J} \ln$.Ring Road Utara, Condong Catur,Sleman, Yogyakarta \\ Email: hikmah@amikom.ac.id, rumini@amikom.ac.id
}

(Diterima: 21 Agustus 2019, direvisi: 2 November 2019, disetujui: 10 November 2019)

\begin{abstract}
Book lending is a form of service provided by the library. Borrowing is very closely related to inventory. In library A in determining the inventory of books, library staff has difficulty in determining what types of books are needed by students. Where the determination of the number and type of books has not used a definite calculation system, only based on the estimated number of students and courses of each study program. Therefore a classification of borrowing types of books is needed based on student book lending transactions, the data used in this study were 269,116 from 2014 to 2019 months 6. The types of books processed were 184 types of books from 1700 types of books, the first step carried out perform forecasting techniques to predict the target inventory of each type of book in the following year, the second stage of the book lending transaction data is processed to determine the classification of book types using neural network backpropagation. Obtained the results of the error rate or MSE of 0.021, using hidden layer 9 and the activation function tansiq with epoch 2000 , with the recommended number of book types recommended for restocking as many as 86 types of books with the number of predictions in each type of book. The third stage is to test the data validation to determine the level of classification and prediction errors, the last step is a regression test that shows a significant correlation of 0.006 with the data variables being tested namely prediction, classification and target data. The results of this study can provide book type recommendation data. along with the number of predictions in each type of book needed in the coming year using the neural network backpropagation method with an accuracy rate of $95.5 \%$.
\end{abstract}

Keywords: Book Type, Neural Network Backpropagation, Classification, Prediction

\begin{abstract}
ABSTRAK
Peminjaman buku merupakan salah satu wujud pelayanan yang diberikan oleh perpustakaan. Peminjaman sangat erat kaitannya dengan persediaan. Pada perpustakaan A dalam menentukan persediaan buku, pegawai perpustakaan kesulitan untuk menentukan jenis-jenis buku apa saja yang sangat dibutuhkan mahasiswa. Dimana penentuan jumlah dan jenis buku belum menggunakan sistem perhitungan yang pasti, hanya berdasarkan perkiraan jumlah mahasiswa dan matakuliah setiap program studi. Maka dari itu dibutuhkan klasifikasi peminjaman jenis buku berdasarkan transaksi peminjaman buku mahasiswa, data yang digunakan dalam penelitian ini yang sebanyak 269.116 dari tahun 2014 sampai 2019 bulan ke 6. Data jenis buku yang diolah sebanyak 184 jenis buku dari 1700 jenis buku, tahapan pertama yang dilakukan melakukan teknik forecasting untuk meramalkan target persediaan setiap jenis buku pada tahun selanjutya, tahapan kedua data transaksi peminjaman buku diproses untuk mengetahui klasifikasi jenis buku dengan menggunakan neural network backpropagation. Didapatkan hasil tingkat error atau MSE sebesar 0,021, menggunakan layer hidden 9 dan fungsi aktivasi tansiq dengan epoch 2000, dengan rekomendasi jumlah jenis buku yang disarankan untuk restock sebanyak 86 jenis buku dengan jumlah prediksi disetiap jenis buku. Tahapan ketiga melakukan pengujian validasi data untuk mengetahui tingkat error klasifikasi dan prediksi, terakhir dilakukan uji regresi menunjukan hasil hubungan yang siqnifikan sebesar 0,006 dengan data variabel yang dujikan yaitu data prediksi, klasifikasi dan target.. Hasil dari penelitian ini adalah dapat memberikan data rekomendasi jenis buku beserta jumlah prediksi di setiap jenis buku yang dibutuhkan ditahun yang akan datang dengan menggunakan metode neural network backpropagation dengan tingkat akurasi sebesar 95,5\%.
\end{abstract}


Kata Kunci: Jenis Buku, Neural Network Backpropagation, Klasifikasi, Prediksi

\section{PENDAHULUAN}

Perpustakaan berfungsi sebagai salah satu faktor yang mempercepat akselerasi transfer ilmu pengetahuan, oleh karenanya perpustakaan merupakan suatu kesatuan yang tidak dapat dipisahkan dalam sistem pendidikan suatu lembaga. Selain itu juga perpustakaan berfungsi sebagai sumber informasi, dan merupakan penunjang yang penting artinya bagi suatu riset ilmiah, sebagai bahan acuan atau referensi[1]. Salah satu pelayanan perpustakaan adalah melayani peminjaman buku, akan tetapi permasalahan dalam menentukan buku apa saja yang paling banyak dibutuhkan oleh mahasiswa hanya berdasarkan laporan mahasiswa, bukan berdasarkan data transaksi peminjaman buku yang ada pada sistem library perpustakaan, sehingga membuat kurang efektifnya dalam pengambilan keputusan jenis buku apa saja yang akan diperbanyak persediaannya.

Keputusan dalam menyediakan persediaan jenis buku berdasarkan permintaan mahasiswa yang diajukan melalui formulir pengajuan buku dan pendapat karyawan perpustakaan terhadap pertanyaan kesediaan buku yang diajukan mahasiswa atau pengunjung secara lisan. Belum berdasarkan data-data yang diolah berdasarkan jumlah transaksi peminjaman yang dianalisis dan dikelompokkan berdasarkan jenis buku yang banyak diminati atau dipinjam. Dalam rangka meningkatkan pelayanan pada sistem informasi perpustakaan ditambahkannya fitur pencarian yang dilengkapi dengan rekomendasi buku[2]

Algoritma perceptron digunakan untuk memprediksi jumlah buku yang pada tahun yang akan datang, dengan cara menganalisa dan mengelompokkan buku yang berkaitan dengan persediaan buku[3]

Pada penelitian ini dilakukan analisis menggunakan forecasting untuk memprediksi data jenis buku pada tahun selanjutnya, sehingga dapat dijadikan acuan dalam penentuan target pada metode neural network backpropagation, sehingga dapat diketahui klasifikasi data jenis buku apa saja yang direstock dan prediksi ditahun berikutnya, dan selanjutnya akan dilakukan pengujian tingkat error berdasarkan hasil data klasifikasi dan target, serta uji regresi untuk mengetahui siqnifikasi hubungan klasifikasi, target, dan prediksi. tujuan dari penelitian ini adalah untuk mengetahui jenis buku yang paling banyak dipinjam mahasiswa dan ramalan jumlah persediaan dan data klasifikasi jenis buku, sehingga dapat memberikan rekemondasi jenis buku apa saja yang akan di restock dan dapat memberikan berapa jumlah berdasarkan jenis buku.

\section{TINJAUAN PUSTAKA}

Pada Penelitian menggunakan metode neural network backpropagation yang optimal dan cukup akurat adalah dengan arsitektur jaringan 4-10-1, yakni 1 lapisan input dengan 4 neuron, 1 lapisan hidden dengan 10 neuron dan 1 lapisan output dengan 1 neuron. Parameter yang digunakan fungsi aktivasi tansig dan fungsi pelatihan trainrp, dengan toleransi error 0,001 , learning rate 0,05 serta maksimum epoch sebanyak 5000. Nilai MSE yang dihasilkan adalah 0,0113 dan nilai koefisien korelasi untuk data pelatihan sebesar 0,961661 serta nilai koefisien korelasi untuk data pengujian sebesar 0,8696[4].

Penelitian ini dilakukan untuk memprediksi harga saham pada bank BRI sebagai bank pemerintah dan BCA sebagai bank v yang merupakan bank terbaik berdasarkan modal intinya yang berada di atas 30 triliun Rupiah pada tahun 2013 berdasarkan data dari majalah info bank. Teknik yang digunakan untuk memprediksi harga saham pada penelitian ini menggunakan metode Back Propagation Neural Network Metode ini sangat sesuai untuk data time series yang bersifat non-linier. Data-data yang digunakan adalah data harga saham pada 4 bank terbesar berdasarkan modal intinya yang berjumlah di atas 30 triliun Rupiah, yaitu bank BRI, Mandiri, BNI dan BCA. Data yang digunakan adalah data harga saham harian selama tahun 2013. Hasil penelitian mengenai prediksi harga saham pada bank BRI dan BCA dengan menggunakan metode BPNN ini memiliki nilai akurasi yang baik, di mana hasil yang diperoleh mendekati data yang sebenarnya[5]

Penelitian ini yaitu FP-Growth. Pada FP-Growth frequent item set diperoleh dari FP-Tree. kemudian di lakukan analisa pola asosiasinya dengan menghitung nilai support dan confident rule. Hasil penelitian ini yaitu sistem informasi perpustakaan yang dilengkapi dengan rekomendasi buku pada fitur pencarian untuk meningkatkan pelayanan sistem informasi perpustakaan[2] 
Algoritma Perceptron adalah salah satu cara memprediksi buku apa saja yang sangat dibutuhkan mahasiswa. Data-data yang berkaitan dengan persedian buku perpustakaan dianalisa dan dikelompokkan. Selanjutnya akan diolah dengan menggunakan jaringan syaraf tiruan yang nantinya akan memberikan suatu output yaitu informasi mengenai persediaan buku perpustakaan yang sesuai kebutuhan mahasiswa di masa yang akan[3]

\subsection{Data Mining}

Data Mining adalah proses yang menggunakan teknik statistik, matematika, kecerdasan buatan, machine learning untuk mengekstraksi dan mengidentifikasi informasi yang bermanfaat dan pengetahuan yang terkait dari berbagai database besar [6]. Terdapat beberapa istilah lain yang memiliki makna sama dengan data mining, yaitu Knowledge discovery in databases (KDD), ekstraksi pengetahuan (knowledge extraction), Analisa data/pola (data/pattern analysis), kecerdasan bisnis (business intelligence) dan data archaeology dan data dredging [7].

Berdasarkan fungsionalitasnya, tugas-tugas data mining dikelompokkan kedalam enam kelompok berikut ini [8]:

1. Klasifikasi (classification), mengeneralisasi struktur yang diketahui untuk diaplikasikan pada data-data baru. Misalkan, klasifikasi penyakit kedalam sejumlah jenis.

2. Klasterisasi (clustering), mengelompokkan data yang tidak diketahui label kelasnya, kedalam sejumlah kelompok tertentu sesuai ukuran kemiripannya

3. Regresi, menemukan suatu fungsi memodelkan data dengan galat (kesalahan prediksi) seminimal mungkin.

4. Deteksi anomali (anomaly detection), mengidentifikasi data yang tidak umum, dapat berupa outlier (pencilan), perubahan atau deviasi yang mungkin sangat penting dan perlu investigasi lebih lanjut.

5. Pembelajaran aturan asosiasi (assosiation rule learning) atau pemodelan kebergantungan (dependency modeling), mencari relasi/hubungan antar variabel.

6. Perangkuman (summarization), menyediakan representasi data yang lebih sederhana, meliputi visualisasi dan pembuatan laporan.

\subsection{Ramalan (Forecasting)}

Peramalan adalah penggunaan data masa lalu dari sebuah variabel atau kumpulan variabel untuk mengestimasi nilainya di masa yang akan datang[9].

FORECAST(x, known_y's, known_x's)

Sintaks fungsi FORECAST memiliki argumen berikut[10]:

- X Diperlukan. Titik data yang ingin Anda prediksikan nilainya.

- Known_y's Diperlukan. Array atau rentang data terikat.

- Known_x's Diperlukan. Array atau rentang data bebas.Keterangan

- Jika x nonnumerik, maka FORECAST mengembalikan \#VALUE! .

- Jika known_y's dan known_x's kosong atau berisi jumlah titik data yang berbeda, FORECAST akan mengembalikan nilai kesalahan \#N/A.

- Jika varians known_x's sama dengan nol, maka FORECAST akan mengembalikan \#DIV/0! .

Persamaan untuk FORECAST adalah a+bx, di mana:

$a=\bar{y}-b \bar{x}$

dan:

$b=\frac{\sum(x-\bar{x})(y-\bar{y})}{\sum(x-\bar{x})^{2}}$

dan di mana $x$ dan y adalah sampel berarti AVERAGE(known_x's) dan AVERAGE(known y's).

a. 2.3 Neural Network 
Neural Network merupakan algoritma komputasi yang memiliki kesamaan dengan sistem jaringan saraf otak manusia. Algoritma ini adalah elemen perhitungan non-linear dasar yang disebut dengan neuron yaitu jaringan yang saling berhubungan, sehingga mirip dengan jaringan saraf otak manusia, dengan tujuan untuk memecahkan contohnya pengenalan pola dan klasifikasi dalam proses pembelajaran[11]

Neural Network ditentukan oleh 3 hal[12]:

1. Pola hubungan antar neuron (disebut arsitektur jaringan).

2. Metode untuk menentukan bobot penghubung (disebut metode training/learning).

3. Fungsi aktifasi, yaitu fungsi yang digunakan untuk menetukan keluaran suatu neuron.

\section{b. 2.4 Probagasi Balik/Backpropagtion}

Propagasi balik atau backpropagation meruapakan suatu teknik pembelajaran/pelatihan supervised leraning yang paling banyak digunakan. Metode ini merupakan salah satu metode yang sangat baik dalam menangani masalah pengenalan pola-pola kompleks.

Didalam jaringan propagasi balik, setiap unit yang berada di lapisan input terhubung dengan setipa unit yang ada dilapisan tersembunyi. Setiap unit yang ada di lapisan tersembunyi terhubung dengan setiap unit yang ada di lapisan output. Jaringan ini terdiri dari banyak lapisan (multilayer network), ketika jaringan diberikan pola masukan sebagai pola pelatihan, maka pola tersebut menuju unit-unit lapisan tersembunyi untuk selanjutnya diteruskan pada unit-unit di lapisan keluaran. Unitunit lapisan keluaran akan memberikan respon sebagai keluaran JST. Saat hasil keluarah tidak sesuai dengan apa yang diharapkan, maka keluaran akan disebarkan mundur (backward) pada lapisan tersembunyi kemudian dari lapisan tersembunyi menuju lapisan masukan [11].

c. 2.5 Arsitektur Propagasi Terbalik

Setiap unit didalam layer input pada jaringan propagasi balik selalu terhubung dengan setiap unit yang berada pada layer tersembunyi, demikian juga setiap unit pada layer tersembunyi selalu terhubung dengan unit pada layer output. Jaringan propagasi balik terdiri dari banyak lapisan (multilayer betwork) [11], yaitu :

2. Lapisan input (1 buah), yang terdiri dari 1 hingga $\mathrm{n}$ unit input.

3. Lapisan tersembunyi (minimal 1 buah), yang terdiri dari 1 hingga $p$ unit tersembunyi.

4. Lapisan output (1 buah), yang terdiri dari 1 hingga m unit output.

\section{Fungsi Aktifikasi Jaringan Terbalik}

a. Fungsi Sigmoid Biner

Fungsi ini merupakan fungsi yang umum digunakan dan akan diterapkan pada aplikasi, rangenya adalah $(0,1)$ dan didefinikan sebagai :

$$
y=\varphi(u)=\frac{1}{1+e^{-u}}
$$

Dengan kurva sebagai berikut :

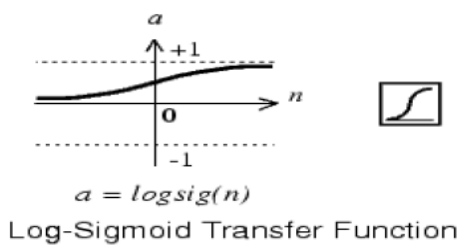

b. Pelatihan Jaringan Propagasi Balik

Aturan pelatihan jaringan propagasi balik terdiri dari 2 tahapan, feedforward dan backward propagation. Pada jaringan diberikan sekumpulan contoh pelatihan yang disebut set pelatihan. Set pelatihan ini digambarkan dengan sebuah vektor feature yang disebut dengan vektor input yang diasosiasikan dengan sebuah output yang menjadi target pelatihannya. 
Dengan kata lain set pelatihan terdiri dari vektor input dan juga vektor output target. Keluaran dari jaringan berupa sebuah vektor output aktual. Selanjutnya dilakukan perbandingan antara output aktual yang dihasilkan dengan output target dengan cara melakukan pengurangan diantara kedua output tersebut. Hasil dari pengurangan merupakan error. Error dijadikan sebagai dasar melakukan perubahan dari setiap bobot yang ada dengan mempropagasikannya kembali [11].

Setiap perubahan bobot yang terjadi dapat mengurangi error. Siklus setiap perubahan bobot (epoch) dilakukan pada setiap set pelatihan hingga kondisi berhenti dicapai yaitu bila jumlah epoch yang diinginkan atau hingga sebuah nilai ambang yang ditetapkan terlampaui. Algoritma propagasi balik terdiri dari 3 tahapan yaitu [12]:

1. Tahapan umpan maju (feedforward)

2. Tahap maju mundur (backpropagation)

3. Tahap peng-update-an $\mathrm{b}$

Berikut ini merupakan algoritma dalam pelatihan Backpropagation Neural Network( BPNN) [13]:

Langkah 0 : Inisialisasi bobot (ambil bobot awal dengan nilai random yang cukup kecil). Tetapkan : Maksimum Epoh, Target Error, dan Learning Rate ( ). Inisialisasi : Epoch = 0, MSE = 1 .

Langkah 1 : Kerjakan langkah-langkah berikut selama (Epoh < Maksimum Epoh) dan (MSE > Target Error) :)

Epoh $=$ Epoh +1.

Langkah 2 : Untuk tiap-tiap pasangan elemen yang akan dilakukan pembelajaran, kerjakan langkah-langkah berikutnya.

Fase I : Feed Forward

Langkah 3 : Tiap-tiap unit input $(\mathrm{Xi}, \mathrm{i}=1,2, \ldots, \mathrm{n})$ menerima sinyal $\mathrm{Xi}$ dan meneruskan sinyal tersebut ke semua unit pada lapisan yang ada di atasnya (lapisan tersembunyi).

Langkah 4 : Tiap-tiap unit pada suatu lapisan tersembunyi $(\mathrm{Zj}, \mathrm{j}=1,2, \ldots, \mathrm{p})$ menjumlahkan sinyal-sinyal input terbobot :

$Z_{-} i n_{j}=b 1_{j}+\sum_{i=1}^{n} X_{i} V_{i j}$

gunakan fungsi aktivasi untuk menghitung sinyal output :

$\mathrm{Z}_{\mathrm{j}}=\mathrm{f}\left(\mathrm{Z}_{\mathrm{in}}\right)_{\mathrm{j}}$

dan kirimkan sinyal tersebut ke semua unit di lapisan atasnya (unit-unit output).

Langkah 5 : Tiap-tiap unit output $\mathrm{Yk}(\mathrm{k}=1,2, \ldots, \mathrm{m})$ menjumlahkan sinyal-sinyal input terbobot : $\mathrm{Y}_{-} \mathrm{in}_{\mathrm{k}}=\mathrm{b} 2_{\mathrm{k}}+\sum_{\mathrm{i}=1}^{\mathrm{p}} \mathrm{Z}_{\mathrm{i}} \mathrm{W}_{\mathrm{jk}}$

gunakan fungsi aktivasi untuk menghitung sinyal output :

$Y_{k}=f\left(Y_{-} i n_{k}\right)$

dan kirimkan sinyal tersebut ke semua unit di lapisan atasnya (unit-unit output).

\section{Fase II : Back Propagation}

Langkah 6 : Tiap-tiap unit output $\mathrm{Yk}(\mathrm{k}=1,2, \ldots, \mathrm{m})$ menerima target pola yang berhubungan dengan pola input pelatihan, hitung informasi errornya :

$\left.\delta=t_{k}-Y_{k}\right) f^{\prime}\left(Y_{-} i n_{k}\right)$

$\varphi 2_{j k}=\delta_{k} Z_{j}$

$\beta 2_{k}=\delta_{k}$

Kemudian hitung koreksi bobot (yang nantinya akan digunakan untuk memperbaiki nilai ) :

$\Delta \mathrm{W}_{\mathrm{jk}}=\alpha \varphi 2_{\mathrm{jk}}$

Hitung juga koreksi bias (yang nantinya akan digunakan untuk memperbaiki nilai ) :

$\Delta \mathrm{b} 2_{\mathrm{k}}=\alpha \beta 2_{\mathrm{k}}$

Langkah 7 :Tiap-tiap unit tersembunyi $\mathrm{Zj} \quad(\mathrm{j}=1,2, \ldots, \mathrm{p})$ menjumlahkan delta inputnya (dari unit-unit yang berada pada lapisan di atasnya : )

$\delta i n_{j}=\sum_{k=1}^{m} \delta 2_{k} W_{j k}$

Kalikan nilai ini dengan turunan dari fungsi aktivasinya untuk menghitung informasi error : $\delta 1_{\mathrm{j}}=\delta \sin _{\mathrm{j}} \mathrm{f}^{\prime}\left(\mathrm{Z}_{-} \mathrm{in}_{\mathrm{j}}\right)$ 
$\varphi 1_{\mathrm{ij}}=\delta 1_{\mathrm{j}} \mathrm{X}_{\mathrm{j}}$

$\beta 1_{\mathrm{j}}=\delta 1_{\mathrm{j}}$

Kemudian hitung koreksi bobot (yang nantinya akan digunakan untuk memperbaiki nilai :

$\Delta \mathrm{V}_{\mathrm{ij}}=\alpha \varphi 1_{\mathrm{ij}}$

Hitung juga koreksi bias (yang nantinya akan digunakan untuk memperbaiki nilai:

$\Delta \mathrm{b} 1_{\mathrm{j}}=\alpha \beta 1_{\mathrm{j}}$

Langkah 8 :Tiap-tiap unit output $\mathrm{Yk}(\mathrm{k}=1,2, \ldots, \mathrm{m})$ memperbaiki bias dan bobotnya $(\mathrm{j}=0,1,2, \ldots, \mathrm{p})$ :

$\mathrm{W}_{\mathrm{jk}}($ baru $)=\mathrm{W}_{\mathrm{jk}}($ lama $)+\Delta \mathrm{W}_{\mathrm{jk}}$

$\mathrm{b} 2_{\mathrm{k}}(\mathrm{baru})=\mathrm{b} 2_{\mathrm{k}}$ (lama) $+\Delta \mathrm{b} 2_{\mathrm{k}}$

Tiap-tiap unit tersembunyi $\mathrm{Zj}(\mathrm{j}=1,2, \ldots, \mathrm{p})$ memperbaiki bias dan bobotnya $(\mathrm{i}=0,1,2, \ldots, \mathrm{n})$ :

$\mathrm{V}_{\mathrm{ij}}$ (baru) $=\mathrm{V}_{\mathrm{ij}}$ (lama) $+\Delta \mathrm{V}_{\mathrm{ij}}$

$\mathrm{b} 1_{\mathrm{j}}(\mathrm{baru})=\mathrm{b} 1_{\mathrm{j}}($ lama $)+\Delta \mathrm{b} 1_{\mathrm{j}}$

Langkah 9 : Hitung $M S E$

$\mathrm{MSE}=\frac{\sum \mathrm{E}^{2}}{\mathrm{n}}$

$\Sigma \mathrm{E}^{2} \quad=$ selisih antara nilai target dengan nilai keluaran prediksi (dikuadratkan)

$\mathrm{N} \quad=$ jumlah data pembelajaran

\section{Langkah 10: Akurasi}

$\%$ akurasi $=\frac{\text { jumlah } \text { klasifikasi benar }}{\text { jumlah data di dataset }} \times 100 \%$

\subsection{Pengujian}

Ada beberapa pengujian yang dilakukan setelah mengetahui hasil klasifikasi menggunakan metode neural network

a) Kinerja model ANN diukur dengan menggunakan rumus persentase error (CPE) [14]

Keterangan:

$\mathrm{CPE}=\underline{\mathrm{E}(\mathrm{i})-\mathrm{T}(\mathrm{i})}$

$\mathrm{T}$ (i) $\mathrm{X} 100 \%$

a. $\mathrm{T}(\mathrm{i})$ : output nilai target

b. E(i) : output nilai klasifikasi hasil ANN

b) Linear Regresi Berganda

Analisis linier berganda adalah di mana variabel terikatnya (Y) dihubungkan atau dijelaskan lebih dari satu variabel, mungkin dua, tiga, dan seterusnya variabel bebas (X1, X2, X3, ..., Xn) namun masih menunjukkan diagram hubungan yang linear. Penambahan variabel bebas ini diharapkan dapat lebih menjelaskan karakteristik hubungan yang ada walaupun masih saja ada variabel yang terabaikan. Bentuk umum persamaan regresi linear berganda dapat dituliskan sebagai berikut[15].

$\mathrm{Y}=\mathrm{a}+\mathrm{b}_{1} \mathrm{X}_{1}+\mathrm{b}_{2} \mathrm{X}_{2}+\mathrm{b}_{3} \mathrm{X}_{3}+\ldots \ldots \ldots \ldots . . .+\mathrm{b}_{\mathrm{k}} \mathrm{X}_{\mathrm{k}}+\mathrm{e}$

Keterangan:

$\mathrm{Y}=$ variabel terikat

$\mathrm{b} 1, \mathrm{~b} 2, \mathrm{~b} 3, \ldots, \mathrm{bk}=$ koefisien regresi

$\mathrm{X} 1, \mathrm{X} 2, \mathrm{X} 3, \ldots, \mathrm{Xk}=$ variabel bebass

$\mathrm{e}=$ kesalahan pengganggu (disturbance terma), artinya nilai- nilai dari variabel lain yang tidak

dimasukkan dalam persamaan. Nilai ini biasanya tidak dihiraukan dalam perhitungan.

\section{METODE PENELITIAN}

Metode penelitian yang dilakukan untuk menganalisa permasalahan diatas menggunakan metode Experiment seperti gambar dibawah ini. 


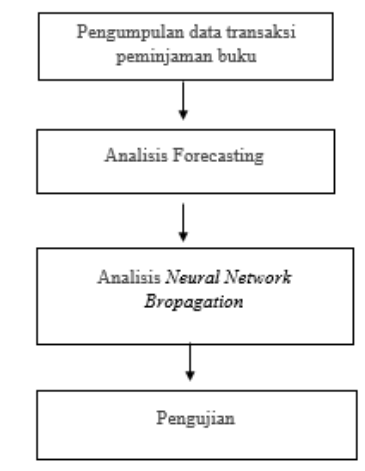

Gambar 1 Alir diagram

Keterangan tahapan detail pada gambar 1 diatas sebagai berikut:

\section{A. Pengumpulan Data}

Pada tahapan ini melakukan rumusan masalah terhadap pola peminjaman buku,analisis kebutuhan data:

a. Sumber Data yang digunakan dalam penelitian ini adalah data hasil transaksi peminjaman data buku pada perpusatakaan resource center Universitas AMIKOM tahun 2014- 2019 dari bulan januari sampai juni.

b. Teknik pengumpulan data adalah dengan cara mengumpulkan data kuantitaf dari data transaksi peminjaman buku

\section{B. Analisis Forecasting}

Analisis data menggunakan forecasting untuk mengetahui pola atau prediksi data jenis buku berdasarkan transaksi peminjaman

\section{Analisis Neural Network Bropagation}

Penelitian dengan menerapakan metode neural network bropagation untuk mengklasifikasi data jenis buku

\section{Pengujian}

Pengujian dilakukan untuk menguji hasil klasifikasi dan uji regresi.

\section{HASIL DAN PEMBAHASAN}

Pada Pembahasan hasil penelitian ini dilakukan dengan tahapan pengumpulan data terlebih dahulu, selanjutnya analisis forecasting dengan tujuan untuk mengetahui data prediksi pada tahun berikutnya, dan dilanjutkan analisis neural network backpropagation, terakhir dilakukan pengujian nilai error dan uji regresi.

\subsection{Pengumpulan Data}

Data yang digunakan berasal dari data transaksi peminjaman buku mahasiswa dari tahun 2014 sampai 2019 bulan ke 6 dengan jumlah keseluruhan 269.116 transaksi. Tahapan dalam penyeleksian data transaksi peminjaman.

1. Pengelompokkan data berdasarkan jenis buku per jumlah transaksi pertahun

2. Data transaksi peminjaman setiap tahun dijumlahkan keseluruhan

3. Data diseleksi, diambil jumlahnya diatas 50 dari keseluruhan transaksi.

4. Data yang digunakan berjumlah 184 jenis buku dari 1700 jenis buku. 
Tabel 1 Contoh Data Transaksi Peminjaman Buku

\begin{tabular}{|c|c|c|c|c|c|c|c|}
\hline Jenis Buku & 2014 & 2015 & 2016 & 2017 & 2018 & 2019 & Jumlah \\
\hline Research, Statistical Methods/Riset, & & & & & & & \\
\hline Metode Statistik & 57 & 63 & 17 & 24 & 24 & 1 & 186 \\
\hline Methods/Metode & & & & & & & \\
\hline Penelitian & 173 & 104 & 113 & 135 & 94 & 27 & 646 \\
\hline Computer Modeling And Simulation & 6 & 33 & 20 & 24 & 6 & 0 & 89 \\
\hline $\begin{array}{l}\text { Data Processing, Computer Science } \\
\text { karya umum tentang tipe khusus }\end{array}$ & 272 & 322 & 238 & 131 & 174 & 44 & 1181 \\
\hline komputer & 59 & 64 & 33 & 8 & 8 & 3 & 175 \\
\hline minicomputers digital & 10 & 13 & 22 & 5 & 3 & 0 & 53 \\
\hline Digital microcomputers & 6 & 8 & 4 & 29 & 54 & 10 & 111 \\
\hline specific digital microcomputers & 32 & 43 & 40 & 4 & 10 & 0 & 129 \\
\hline Systems Analysis and Computer & & & & & & & \\
\hline $\begin{array}{l}\text { Design, Computer Architecture, } \\
\text { Computer Performance Evaluation }\end{array}$ & 510 & 320 & 229 & 127 & 75 & 20 & 1281 \\
\hline Computer architecture & 17 & 119 & 51 & 178 & 73 & 0 & 438 \\
\hline Specific Multiprocessor Computers & 34 & 29 & 14 & 6 & 10 & 0 & 93 \\
\hline Interfacing and Communications & 246 & 271 & 228 & 153 & 91 & 19 & 1008 \\
\hline Intefacing and Communication & & & & & & & \\
\hline Protocols & 247 & 247 & 145 & 165 & 146 & 47 & 997 \\
\hline Kinds of Hardware & 40 & 39 & 26 & 32 & 27 & 51 & 215 \\
\hline Computer Communications & & & & & & & \\
\hline Networks/Jaringan $\quad$ Komunikasi & & & & & & & \\
\hline Komputer & 284 & 298 & 341 & 269 & 196 & 34 & 1422 \\
\hline data transmission modes and data & & & & & & & \\
\hline switching methods & 20 & 8 & 13 & 15 & 7 & 5 & 68 \\
\hline Wide area networks & 14 & 24 & 18 & 7 & 19 & 2 & 84 \\
\hline
\end{tabular}

\subsection{Analisis Forecasting}

Analisis forecasting dilakukan untuk mengetahui berapa prediksi transaksi ditahun yang akan datang yaitu tahun 2020 sehingga dapat dijadikan data pertimbangan dalam menentukan data target yang akan diolah menggunakan metode neural network backpropagation, rumus yang digunakan pada persamaan (1) dan persamaan (2), dengan hasil data pada tabel 2 sebagai berikut

Tabel 2 Contoh Hasil Data Forecasting tahun 2020

\begin{tabular}{|c|c|c|c|c|c|c|c|}
\hline Jenis_Buku & 2014 & 2015 & 2016 & 2017 & 2018 & 2019 & 2020 \\
\hline Research, $\quad$ Statistical & & & & & & & \\
\hline $\begin{array}{l}\text { Methods/Riset, } \quad \text { Metode } \\
\text { Statistik }\end{array}$ & & 63 & 17 & 24 & 20 & 1 & 0 \\
\hline Research Methods/Metode & & & & & & & \\
\hline Penelitian & 173 & 104 & 113 & 135 & 94 & 27 & 34 \\
\hline Computer & & & & & & & \\
\hline Simulation & 6 & 33 & 20 & 24 & 6 & 0 & 4 \\
\hline $\begin{array}{l}\text { Data Processing, Computer } \\
\text { Science }\end{array}$ & 272 & 322 & 238 & 131 & 174 & 44 & 28 \\
\hline karya umum tentang tipe & & & & & & & \\
\hline khusus komputer & 59 & 64 & 33 & 8 & 8 & 3 & 0 \\
\hline minicomputers digital & 10 & 13 & 22 & 5 & 3 & 0 & 0 \\
\hline Digital microcomputers & 6 & 8 & 4 & 29 & 54 & 10 & 37 \\
\hline $\begin{array}{l}\text { specific digital } \\
\text { microcomputers }\end{array}$ & 32 & 43 & 40 & 4 & 10 & 0 & 0 \\
\hline
\end{tabular}

Norhikmah, Rumini, Klasifikasi Peminjaman Buku Menggunakan Neural Network Backpropagation 
Systems Analysis and

Computer Design, Computer

Architecture, Computer

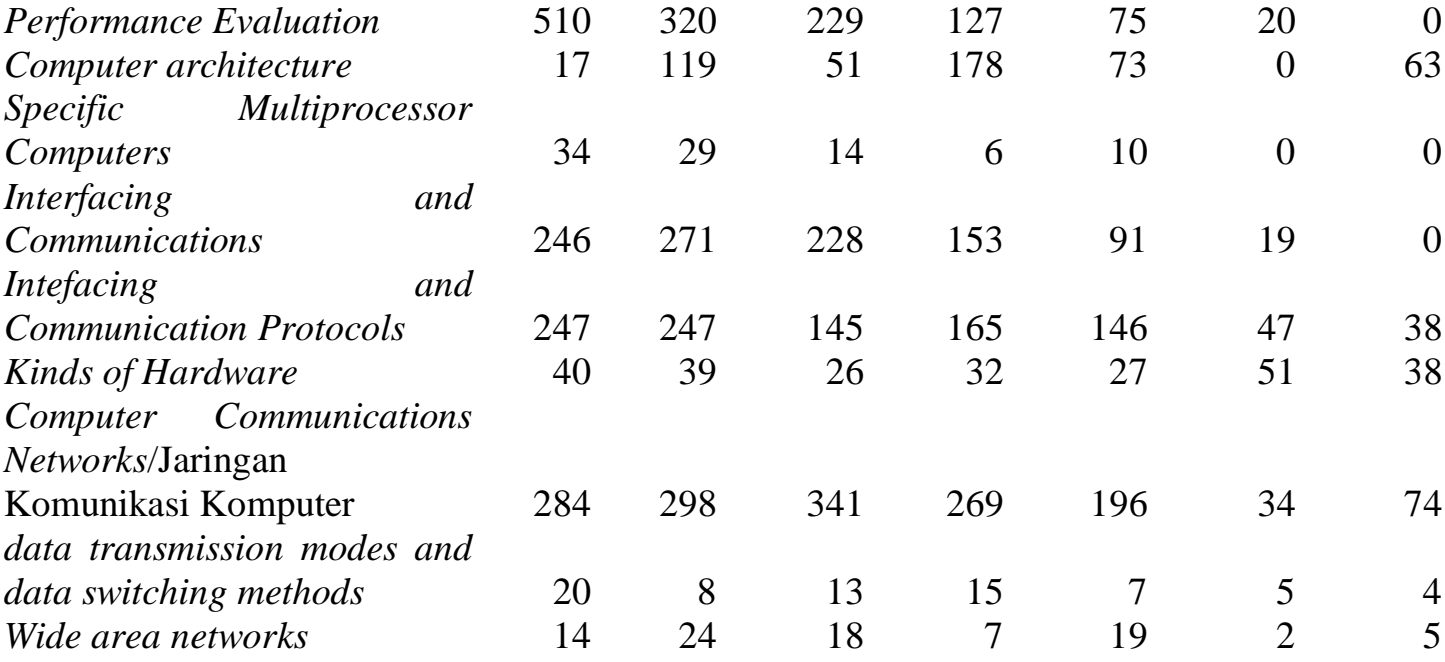

\subsection{Analisis Neural Network backpropagation}

Penyelesaian yang digunakan untuk penentuan pola peminjaman menggunakan neural network. Perangkat lunak yang digunakan MATLAB dan Ms.excel digunakan untuk pengolahan data. Ada beberapa tahapan yang dilakukan: tahapan pemodelan, tahapan pelatihan dan pengujian.

a. Tahapan Pemodelan

Pada tahapan ini adalah perancangan arsitektur neural network, menentukan jumlah lapisan tersembunyi dan jenis fungsi aktivasi terbaik yang digunakan berdasarkan hasil exprimen yang dilakukan.pada tabel dibawah ini, dengan menggunakan perhitungan persamaan(3)sampai persamaan(11):

Tabel 3 Tabel Exprimen Neural Network Backpropagation

$\begin{array}{rrlrrrr}\text { Expriment } & \text { Layer Hidden } & \text { Aktivasi } & \text { Epoch } & \text { Goal } & \text { Mse } & \text { Validasi } \\ 1 & 9 & \text { Tansiq } & 5000 & 0,1 & 0,039 & 0,918 \\ 2 & 9 & \text { Purline } & 5000 & 0,1 & 0,125 & 0,735 \\ 3 & 9 & \text { Logsig } & 5000 & 0,1 & 0,09 & 0,829 \\ 4 & 9 & \text { Tansiq } & 1000 & 0,1 & 0,1 & 0,777 \\ 5 & 9 & \text { Purline } & 1000 & 0,1 & 0,038 & 0,919 \\ 6 & 9 & \text { Logsig } & 1000 & 0,1 & 0,069 & 0,86 \\ 7 & 9 & \text { Tansiq } & 2000 & 0,1 & 0,021 & 0,959 \\ 8 & 9 & \text { Purline } & 2000 & 0,1 & 0,054 & 0,892 \\ 9 & 9 & \text { Tansiq } & 3000 & 0,1 & 0,397 & 0,912 \\ 10 & 9 & \text { Purline } & 3000 & 0,1 & 0,115 & 0,718 \\ 11 & 9 & \text { Logsig } & 3000 & 0,1 & 0,323 & 0,936 \\ 12 & 9 & \text { Tansiq } & 4000 & 0,1 & 0,051 & 0,913 \\ 13 & 9 & \text { Purline } & 4000 & 0,1 & 0,051 & 0,906 \\ 14 & 9 & \text { Logsig } & 4000 & 0,1 & 0,12 & 0,718\end{array}$

Dari tabel 3 diatas didapatkan data hasil exprimen terbaik yang digunakan sebagai parameter pembelajaran yang digunakan: Layer 1 neorun hidden: 9, aktifasi:Tansiq, Epoch : 2000,goal: 0,1 
Sehingga dihasilkan nilai Mse:0,021 dan nilai Validasi 0,959, ditunjukan lebih detail pada gambar 24 grafik dibawah ini:

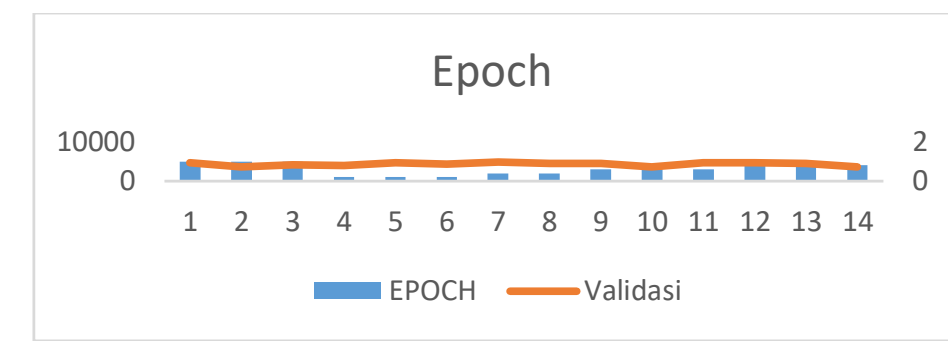

Gambar 2 Hasil grafik epoch dan validasi

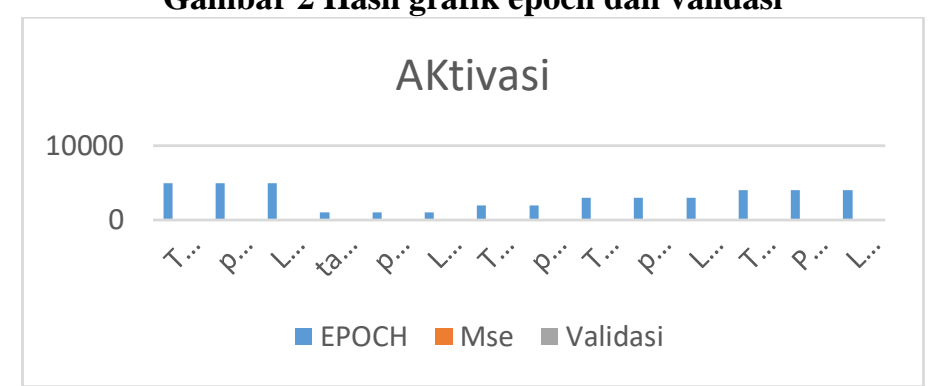

Gambar 3 Hasil grafik aktivasi

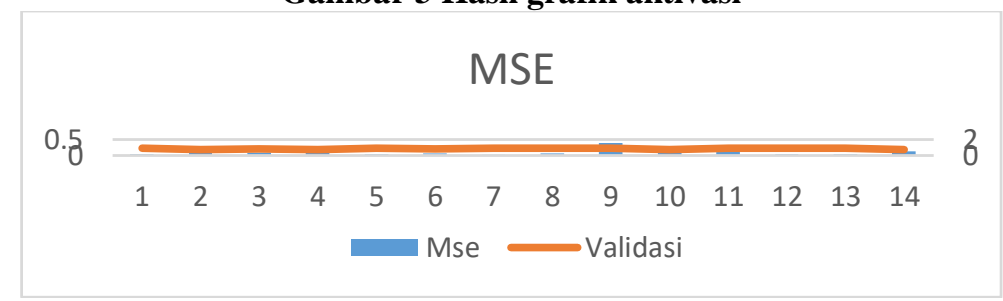

Gambar 4 Hasil grafik MSE

Berikut adalah hasil pelatihan menggunakan matlab:

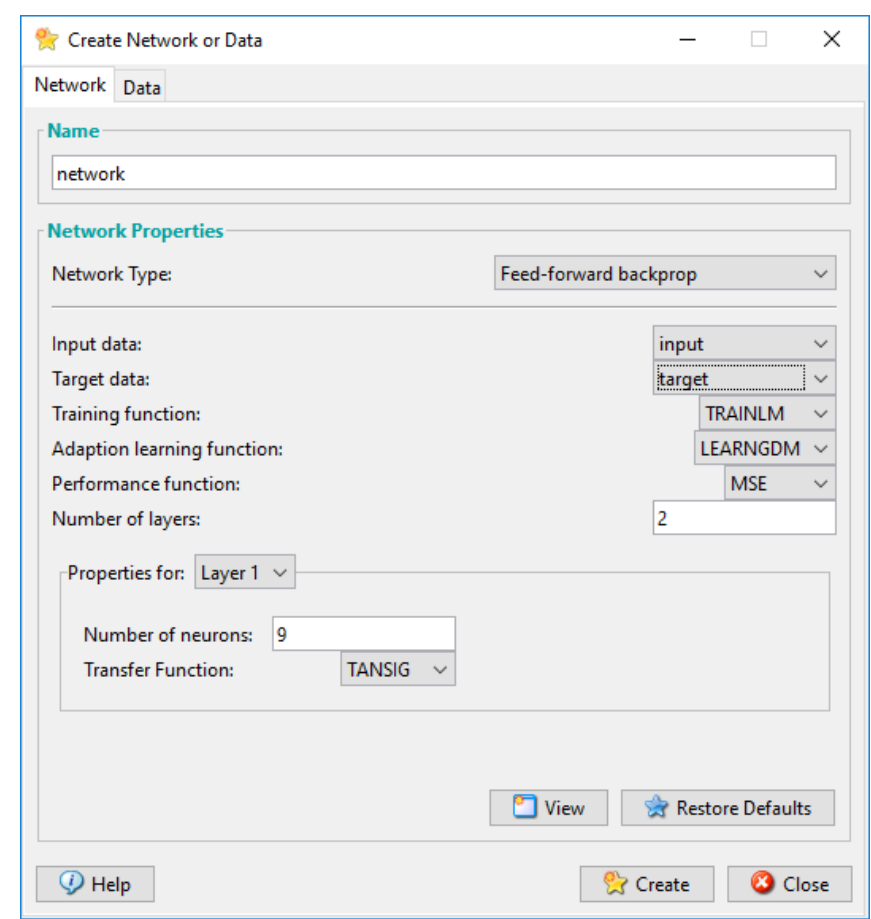

Gambar 5 Setting pelatihan menggunakan backpropagation

Norhikmah, Rumini, Klasifikasi Peminjaman Buku Menggunakan Neural Network Backpropagation 
Pada Gambar 5 sebelum melakukan pelatihan ,diperlukannya disetting terlebih dahulu,sebagai berikut:

a) Type Network: Backpropagation

b) Jumlah layer : 1

c) Neuron : 9 hidden layer

d) Fungsi aktivasi : Tansiq

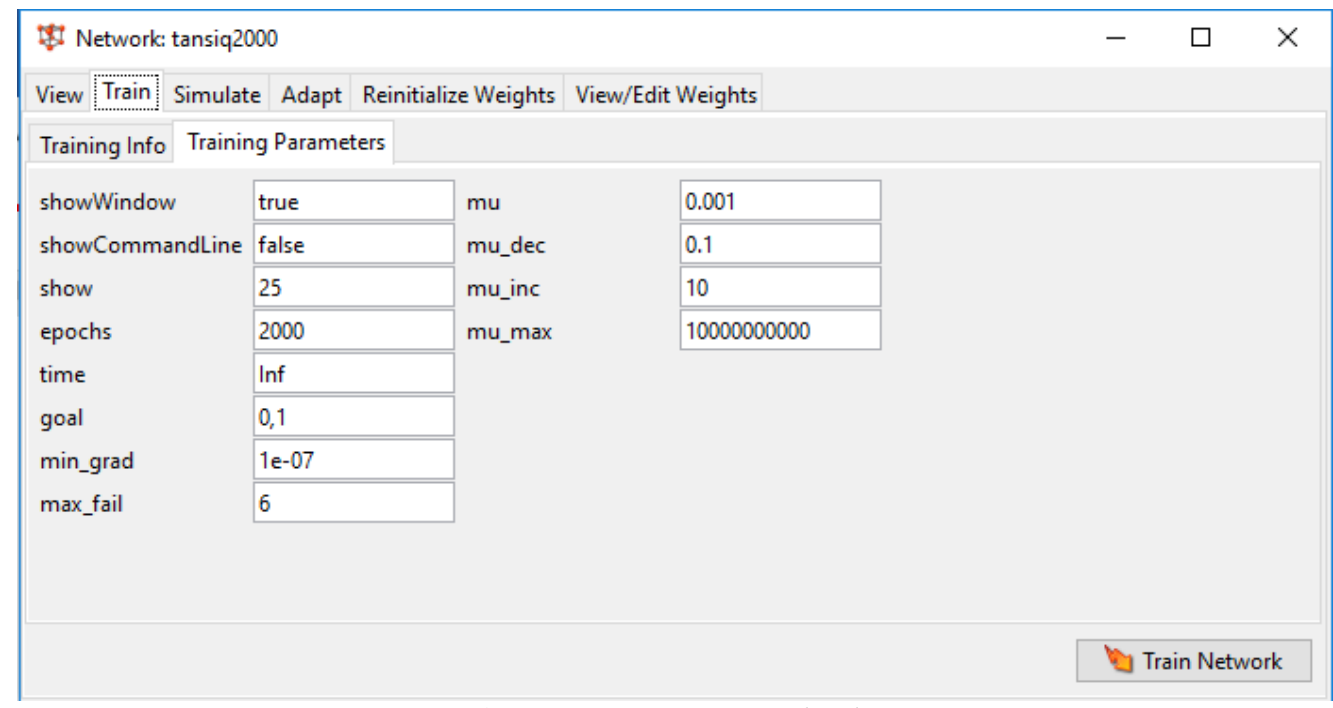

\section{Gambar 6 Setting pembelajaran backpropagation}

Pada gambar 6 diatas mensetting pembelajaran pelatihan, dengan nilai epoch 2000 dengan nilai goal 0,1 .

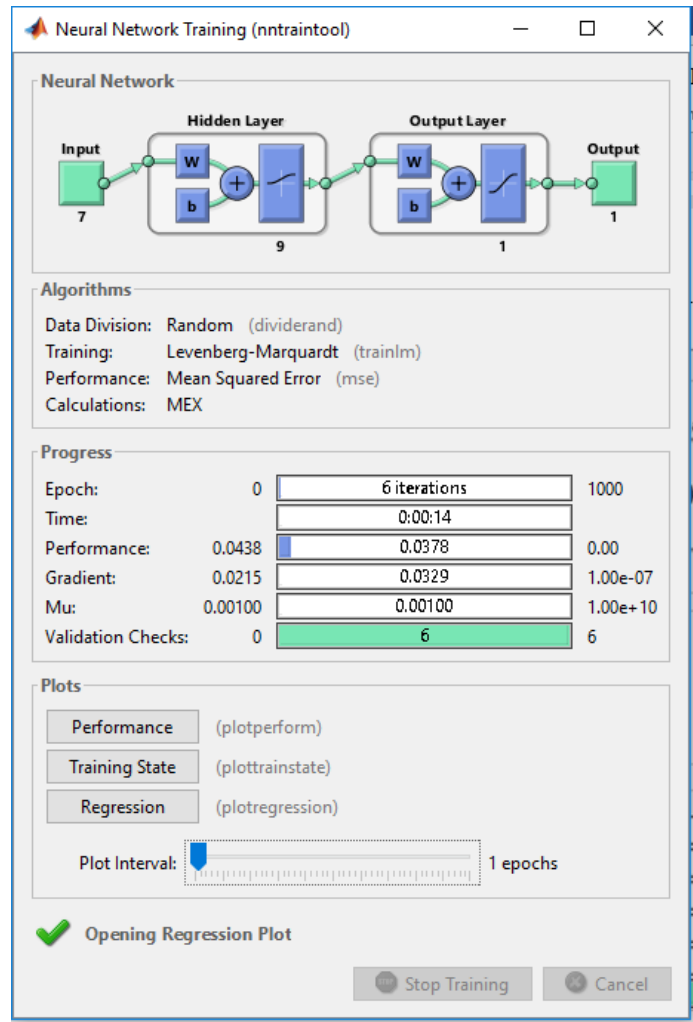

Gambar 7 Hasil training

Pada gambar 7 diatas hasil training dengan iterasi 0,6 dengan jumlah waktu 14 detik, performance 0.043, dengan Gradient 0.021 dan validasi check 6 . 


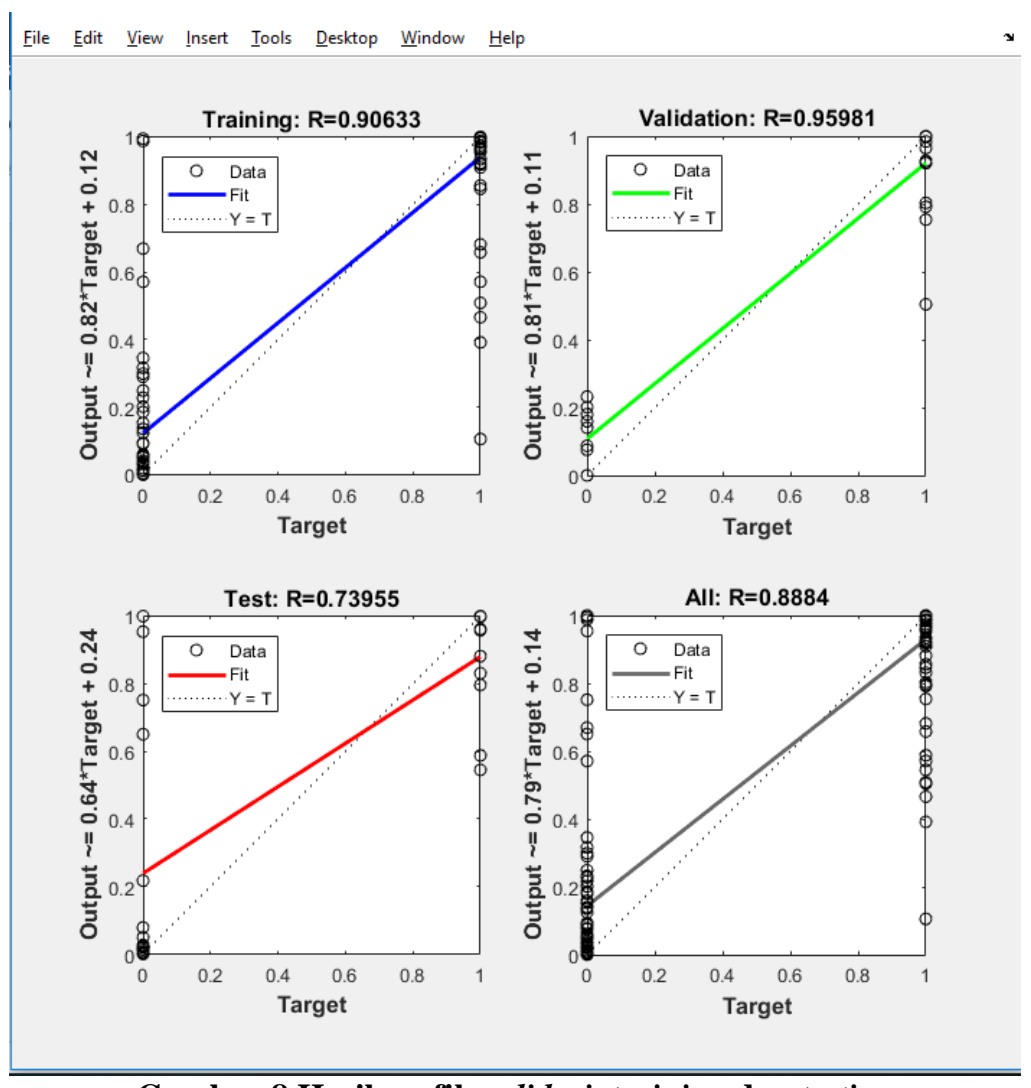

Gambar 8 Hasil grafik validasi, training dan testing

Pada Gambar 8 diatas disimpulkan dengan nilai validasi 0.925, nilai korelasi data training 0.905 , nilai korelasi testing 0.739 . nilai hasil keseluruhan 0,088

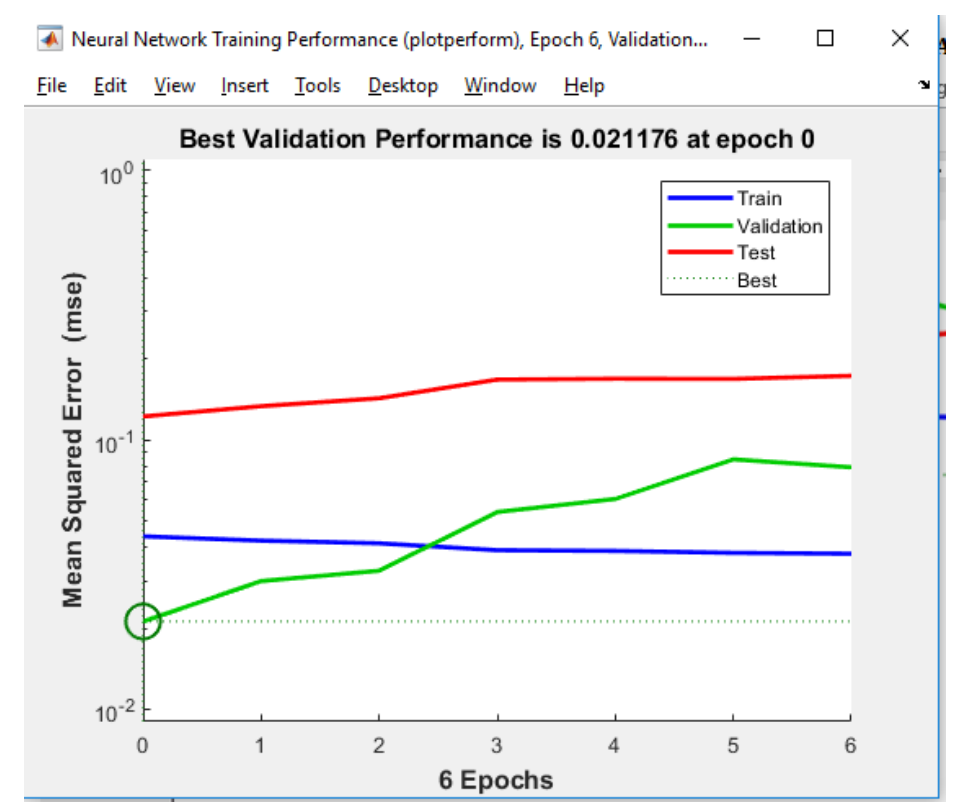

Gambar 9 Nilai Mse 
Gambar 9 diatas terdapat nilai terbaik pada error Mse 0,021 dari epoch 0

Tabel 4 Hasil Klasifikasi dan Prediksi

\begin{tabular}{|c|c|c|c|}
\hline Jenis Buku & $\begin{array}{l}\text { Hasil } \\
\text { Klasifikasi } \\
\text { ANN }\end{array}$ & $\begin{array}{c}\text { Keterangan } \\
\text { Stock(Ya/Tidak) }\end{array}$ & $\begin{array}{l}\text { Prediksi Stock } \\
\text { jumlah buku } \\
\text { ditahun } 2020\end{array}$ \\
\hline $\begin{array}{l}\text { Research, Statistical Methods/Riset, Metode } \\
\text { Statistik }\end{array}$ & 0.041512 & Tidak & 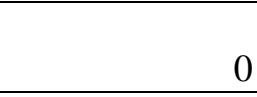 \\
\hline Research Methods/Metode Penelitian & 1 & $\mathrm{Ya}$ & 34 \\
\hline Computer Modeling And Simulation & 0.66928 & Ya & 4 \\
\hline Data Processing, Computer Science & 1 & Ya & 28 \\
\hline karya umum tentang tipe khusus komputer & 0.019517 & Tidak & 0 \\
\hline minicomputers digital & 0.15283 & Tidak & 0 \\
\hline Digital microcomputers & 1 & Ya & 37 \\
\hline specific digital microcomputers & 0.023548 & Tidak & 0 \\
\hline $\begin{array}{l}\text { Systems Analysis and Computer Design, } \\
\text { Computer Architecture, Computer } \\
\text { Performance Evaluation }\end{array}$ & 0.011567 & Tidak & 0 \\
\hline Computer architecture & 1 & Ya & 63 \\
\hline Specific Multiprocessor Computers & 0.03529 & Tidak & 0 \\
\hline Interfacing and Communications & 0.075488 & Tidak & 0 \\
\hline Intefacing and Communication Protocols & 1 & Ya & 38 \\
\hline Kinds of Hardware & 1 & Ya & 38 \\
\hline $\begin{array}{l}\text { Computer Communications Networks/Jaringan } \\
\text { Komunikasi Komputer }\end{array}$ & 1 & Ya & 74 \\
\hline $\begin{array}{l}\text { data transmission modes and data switching } \\
\text { methods }\end{array}$ & 0.98709 & Ya & 4 \\
\hline Wide area networks & 0.95486 & Ya & 5 \\
\hline
\end{tabular}

Pada tabel 4 hasil klasifikasi terdapat jenis buku yang direkomendasikan ya berjumlah 86, dan yang tidak direkomendasikan restock sebanyak 98 jenis buku, dari jumlah keseluruhan nilai jenis buku sebanyak 184 jenis buku. 


\subsection{Pengujian}

Tabel 5 Contoh Pengujian Nilai Error Prediksi Neural Network

\begin{tabular}{|c|c|c|c|}
\hline \multirow[b]{2}{*}{ Jenis buku } & \multicolumn{3}{|c|}{ Prediksi Neural } \\
\hline & Target & Network & error \\
\hline $\begin{array}{l}\text { Research, Statistical Methods/Riset, Metode } \\
\text { Statistik }\end{array}$ & 0 & 0,041512 & -1 \\
\hline Research Methods/Metode Penelitian & 1 & 1 & 0 \\
\hline Computer Modeling And Simulation & 0 & 0,66928 & -1 \\
\hline Data Processing, Computer Science & 1 & 1 & 0 \\
\hline karya umum tentang tipe khusus komputer & 0 & 0,019517 & -1 \\
\hline minicomputers digital & 0 & 0,15283 & -1 \\
\hline Digital microcomputers & 1 & 1 & 0 \\
\hline specific digital microcomputers & 0 & 0,023548 & -1 \\
\hline $\begin{array}{l}\text { Systems Analysis and Computer Design, Computer } \\
\text { Architecture, Computer Performance Evaluation }\end{array}$ & 0 & 0,011567 & -1 \\
\hline Computer architecture & 1 & 1 & 0 \\
\hline Specific Multiprocessor Computers & 0 & 0,03529 & -1 \\
\hline Interfacing and Communications & 0 & 0,075488 & -1 \\
\hline Intefacing and Communication Protocols & 1 & 1 & 0 \\
\hline Kinds of Hardware & 1 & 1 & 0 \\
\hline $\begin{array}{l}\text { Computer Communications Networks/Jaringan } \\
\text { Komunikasi Komputer }\end{array}$ & 1 & 1 & 0 \\
\hline $\begin{array}{l}\text { data transmission modes and data switching } \\
\text { methods }\end{array}$ & 1 & 0,98709 & 0,013078848 \\
\hline Wide area networks & 1 & 0,95486 & 0,047273946 \\
\hline
\end{tabular}

Pada tabel 5 diatas menunjukkan nilai error setiap jenis buku yang didapat dari perhitungaan selisih variabel target dan klasifikasi prediksi neural network, seperti pada rumus perssamaan (12)

Tabel 6 Tabel Hasil Uji Regresi

ANOVA

\begin{tabular}{lrcccr}
\hline & $d f$ & \multicolumn{1}{c}{$S S$} & $M S$ & $F$ & Significance $F$ \\
\hline Regression & 2 & 52587,57 & 26293,78 & 5,239497 & 0,006136885 \\
Residual & 181 & 908326,7 & 5018,379 & & \\
Total & 183 & 960914,2 & & & \\
\hline
\end{tabular}

Pada tabel 6 diatas menggunakan:

Data Y variabel terikat : yaitu hasil prediksi

Data $\mathrm{X}$ variabel bebas : yaitu variabel klasifikasi dan target

Hipotesis:

Ho= Ada hubungan linier antara variabel

$\mathrm{H} 1=$ Tidak ada hubungan linier antara variabel

Pengujian dilakukan mengunakan signifikan atau sig dengan ketentuan sebagai berikut:

Jika angka siqnifikasi penelitian < 0,05: maka $\mathrm{HO}$ ditolak dan $\mathrm{H} 1$ diterima

Jika angka siqnifikasi penelitian >0,05: maka $\mathrm{H} 1$ diterima dan $\mathrm{H} 0$ ditolak

Menggunakan rumus pers.(13). Menunjukkan hasil nilai siqnifikan $0.006<0.05$, yang artinya hubungan variabel prediksi dengan variabel klasifikasi dan target signifikan dibawah nilai 0.05. 


\section{KESIMPULAN}

Kesimpulan dari penelitian ini adalah prediksi dan klasifikasi setiap jenis buku dan jumlah disetiap jenis buku, dengan prediksi perhitungan menggunakan forecasting sedangkan klasifikasi jenis buku menggunakan neural network backpropagation, dengan hasil exprimens didapatkan data akurasi terbaik dan tingkat error terkecil yaitu terdapat pada fungsi aktivasi tansiq, pada epoch 2000 dengan tingkat akurasi 95,5\% dengan error atau Mse 0,021, sehingga mendapatkan data rekomendasi yang restock sebanyak 86 jenis buku. Pengujian menggunakan uji regresi didapatkan hasil yang signifikan sebesar 0,006 , dengan data variabel yang dujikan yaitu data prediksi, klasifikasi dan target.

\section{REFERENSI}

[1] Http://pp.ktp.fip.unp.ac.id/?p=38, "perpustakaan,” in 26 Maret, 2019.

[2] R. A. Hardiyanti Yunika Dinna, Novianto Hardini, "Penerapan Algoritma Fp-Growth Pada Sistem," vol. 3, no. 1, pp. 75-77, 2018.

[3] A. Taufik and A. Afkari, "Analisa Metode Perceptron Prediksi Penyediaan Buku Perpustakaan Sesuai Kebutuhan Mahasiswa (Studi Kasus di Universitas Islam Negeri Sumatera Utara Medan) Ahmad Taufik Al Afkari Siahaan," vol. 6341, no. November, pp. 10-20, 2018.

[4] S. Nanik, "Penerapan Model Neural Network Backpropagation Menentukan Harga Ayam," pp. 325-332, 2014.

[5] A. Novita, "Prediksi Pergerakan Harga Saham Pada Bank Terbesar Di Indonesia Dengan Metode Backpropagation Neural Network," Jutisi, vol. 05, no. 01, pp. 965-972, 2016.

[6] Turban.E, Decision Support Systems and Intelligent Systems Edisi Bahasa Indonesia Jilid 1. Yogyakarta: Andi, 2005.

[7] D. T. Larose, Discovering Knowledge in Data: An Introduction to Data Mining. John Willey \& Sons, Inc, 2005.

[8] U. Fayyad, Advances in Knowledge Discovery and Data Mining. MIT Press.

[9] Murahartawaty, "Peramalan," Jakarta, 2009.

[10] Https://support.office.com/id-id/article/forecast-fungsi-forecast-50ca49c9-7b40-4892-94e47ad38bbeda99, "forecasting.".

[11] M. S. c. D. Jong Jek Siang, Jaringan Saraf Tiruan dan Pemrogramannya Menggunakan Matlab. Yogyakarta: Andi, 2004.

[12] D. Pustpitaningrum, Pengantar Jaringan Saraf Tiruan. Yogyakarta: Andi, 2006.

[13] S. Kusumadewi, Membangun Jaringan Syaraf Tiruan Menggunakan MATLAB \& EXCEL LINK. Yogyakarta: Graha Ilmu, 2004.

[14] A. Y. Prathama, "Pendekatan Ann (Artificial Neural Network) Untuk Penentuan Prosentase Bobot Pekerjaan Dan Estimasi Nilai Pekerjaan Struktur Pada Rumah Sakit Pratama," $J$. Teknosains, vol. 7, no. 1, p. 14, 2018.

[15] J. Sarwono, Analisis Data Penelitian menggunakan SPSS 13. Yogyakarta: Andi, 2006. 